\title{
HOCl chemistry in the Antarctic Stratospheric Vortex 2002, as observed with the Michelson Interferometer for Passive Atmospheric Sounding (MIPAS)
}

\author{
T. von Clarmann ${ }^{1, *}$, N. Glatthor ${ }^{1}$, R. Ruhnke ${ }^{1}$, G. P. Stiller ${ }^{1}$, O. Kirner ${ }^{1}$, T. Reddmann ${ }^{1}$, M. Höpfner ${ }^{1}$, S. Kellmann ${ }^{1}$, \\ W. Kouker ${ }^{1}$, A. Linden ${ }^{1}$, and B. Funke ${ }^{2}$ \\ ${ }^{1}$ Forschungszentrum Karlsruhe and Karlsruhe University, Institut für Meteorologie und Klimaforschung, Karlsruhe, Germany \\ ${ }^{2}$ Instituto de Astrofísica de Andalucía, CSIC, Granada, Spain \\ *now also at: Univ. de Toulouse, UPS, CNRS, Laboratoire d'Aérologie, 14 avenue Edouard Belin, 31400 Toulouse, France
}

Received: 24 July 2008 - Published in Atmos. Chem. Phys. Discuss.: 4 November 2008

Revised: 24 February 2009 - Accepted: 27 February 2009 - Published: 12 March 2009

\begin{abstract}
In the 2002 Antarctic polar vortex enhanced $\mathrm{HOCl}$ mixing ratios were detected by the Michelson Interferometer for Passive Atmospheric Sounding both at altitudes of around $35 \mathrm{~km}(1000 \mathrm{~K}$ potential temperature), where $\mathrm{HOCl}$ abundances are ruled by gas phase chemistry and at around $18-24 \mathrm{~km}(475-625 \mathrm{~K})$, which belongs to the altitude domain where heterogeneous chlorine chemistry is relevant. At altitudes of 33 to $40 \mathrm{~km}$ polar vortex $\mathrm{HOCl}$ mixing ratios were found to be around $0.14 \mathrm{ppbv}$ as long as the polar vortex was intact, centered at the pole, and thus received relatively little sunlight. This is the altitude region where in midlatitudinal and tropic atmospheres peak $\mathrm{HOCl}$ mixing ratios significantly above $0.2 \mathrm{ppbv}$ (in terms of daily mean values) are observed. After deformation and displacement of the polar vortex in the course of a major warming, $\mathrm{ClO}$-rich vortex air was more exposed to sunlight, where enhanced $\mathrm{HO}_{\mathrm{x}}$ abundances led to largely increased $\mathrm{HOCl}$ mixing ratios (up to $0.3 \mathrm{ppbv}$ ), exceeding typical midlatitudinal and tropical amounts significantly. The $\mathrm{HOCl}$ increase was preceded by an increase of ClO. Model runs could reproduce these measurements only when the Stimpfle et al. (1979) rate constant for the reaction $\mathrm{ClO}+\mathrm{HO}_{2} \rightarrow \mathrm{HOCl}+\mathrm{O}_{2}$ was used but not with the current JPL recommendation. At an altitude of $24 \mathrm{~km}, \mathrm{HOCl}$ mixing ratios of up to $0.15 \mathrm{ppbv}$ were detected. This $\mathrm{HOCl}$ enhancement, which is already visible in 18 September data, is attributed to heterogeneous chemistry, which is in agreement with observations of polar stratospheric clouds. The measurements were compared to a model run where no polar stratospheric clouds appeared during the observation period. The fact that $\mathrm{HOCl}$ still was produced in the model run sug-
\end{abstract}

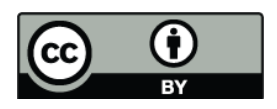

Correspondence to: $\mathrm{T}$. von Clarmann (thomas.clarmann@imk.fzk.de) gests that a significant part of $\mathrm{HOCl}$ was generated from $\mathrm{ClO}$ rather than directly via heterogeneous reaction. Excess $\mathrm{ClO}$, lower $\mathrm{ClONO}_{2}$ and earlier loss of $\mathrm{HOCl}$ in the measurements are attributed to ongoing heterogeneous chemistry which is not reproduced by the model. On 11 October, polar vortex mean daytime mixing ratios were only 0.03 ppbv.

\section{Introduction}

The HOCl catalytic cycle (Solomon et al., 1986) is an important mechanism for mid-latitude stratospheric ozone loss (Lary, 1997):

$$
\begin{aligned}
\mathrm{ClO}+\mathrm{HO}_{2} & \rightarrow \mathrm{HOCl}+\mathrm{O}_{2} \\
\mathrm{HOCl}+h v & \rightarrow \mathrm{OH}+\mathrm{Cl} \\
\mathrm{Cl}+\mathrm{O}_{3} & \rightarrow \mathrm{ClO}+\mathrm{O}_{2} \\
\mathrm{OH}+\mathrm{O}_{3} & \rightarrow \mathrm{HO}_{2}+\mathrm{O}_{2}
\end{aligned}
$$$$
\text { Net: } 2 \mathrm{O}_{3} \rightarrow 3 \mathrm{O}_{2}
$$

Other $\mathrm{HOCl}$ removal reactions are

$\mathrm{HOCl}+\mathrm{OH} \rightarrow \mathrm{H}_{2} \mathrm{O}+\mathrm{ClO}$

and

$\mathrm{HOCl}+\mathrm{O} \rightarrow \mathrm{ClO}+\mathrm{OH}$,

which is more efficient at higher altitudes if enough atomic oxygen is available. Further, in winter polar stratospheric vortices $\mathrm{HOCl}$ is generated by heterogeneous chemistry:

$\mathrm{ClONO}_{2}(\mathrm{~g})+\mathrm{H}_{2} \mathrm{O}(\mathrm{l}, \mathrm{s}) \rightarrow \mathrm{HOCl}(\mathrm{g})+\mathrm{HNO}_{3}(\mathrm{l}, \mathrm{s})$

Published by Copernicus Publications on behalf of the European Geosciences Union. 
and further converted to $\mathrm{Cl}_{2}$, a precursor of ozone depleting $\mathrm{ClO}_{\mathrm{x}}$ radicals, via the heterogeneous reaction

$\mathrm{HOCl}(\mathrm{g})+\mathrm{HCl}(\mathrm{l}, \mathrm{s}) \rightarrow \mathrm{Cl}_{2}(\mathrm{~g})+\mathrm{H}_{2} \mathrm{O}(\mathrm{l}, \mathrm{s})$

(Hanson and Ravishankara, 1992; Abbatt and Molina, 1992; Crutzen et al., 1992; Prather, 1992), where (g), (1), and (s) indicate gaseous, liquid or solid phase, respectively, for typical polar stratospheric conditions.

However, there do not exist many experimental data which can be used to study polar stratospheric $\mathrm{HOCl}$ chemistry quantitatively. Midlatitudinal $\mathrm{HOCl}$ measurements are available from balloon- and airborne infrared solar absorption measurements (Larsen et al., 1985; Toon et al., 1992), spaceborne infrared solar occultation measurements (Raper et al., 1987), and balloon-borne far infrared limb emission measurements (Chance et al., 1989; Traub et al., 1990; Johnson et al., 1995). Arctic stratospheric balloon-borne infrared limb emission measurements were analyzed for $\mathrm{HOCl}$ by von Clarmann et al. (1997). Kovalenko et al. (2007) have found that the rate constant for Reaction (R1) as suggested by Stimpfle et al. (1979) is more consistent with both infrared solar occultation and far infrared emission measurements of $\mathrm{HOCl}$ than the current JPL recommendation (Sander et al., 2006). The first global $\mathrm{HOCl}$ distribution was measured with the Michelson Interferometer for Passive Atmospheric Sounding (MIPAS) (von Clarmann et al., 2006). These data give evidence of enhanced abundances in the Antarctic polar vortex at an altitude of approximately 18-24 km (475$625 \mathrm{~K}$ ). This enhancement was attributed to heterogeneous chemistry, since polar stratospheric clouds had been observed in advance of these measurements (Höpfner et al., 2004) (see also Fig. 1). In this paper, the temporal development of Antarctic stratospheric $\mathrm{HOCl}$ abundances is analyzed in more detail and put into the context of MIPAS $\mathrm{ClO}$ (Glatthor et al., 2004) and $\mathrm{ClONO}_{2}$ (Höpfner et al., 2004) measurements. In order to better understand the temporal development of the measured abundances of chlorine species, these are compared to those calculated with the Karlsruhe Simulation Model of the Middle Atmosphere (KASIMA; Kouker et al. 1999; Ruhnke et al. 1999a; Reddmann et al. 2001).

\section{The Antarctic winter 2002}

While some indication of perturbed dynamics had been observed already in the early phase of the Antarctic stratospheric vortex in Austral winter 2002, the vortex behaved more or less as usual from mid-winter up to around 20 September (Figs. 2 and 3). Enhanced $\mathrm{ClO}$ in the altitude region between 16 and $23 \mathrm{~km}$ gave evidence of chlorine activation (Glatthor et al., 2004). PSCs were observed until 22 September (Höpfner et al. 2004; see Fig. 1), making heterogeneous chemistry possible. In the course of a major warming around 20 September (Allen et al., 2003; Krüger et al.,

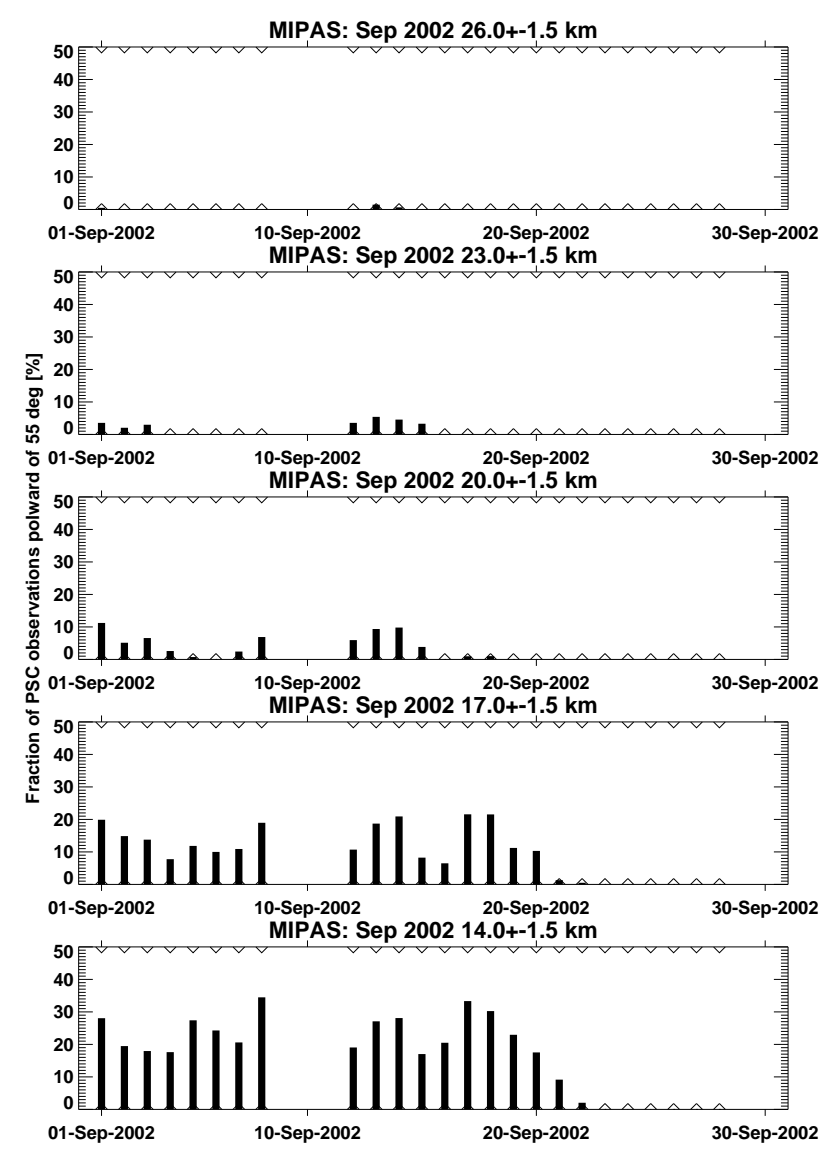

Fig. 1. Time series of relative PSC coverage (ratio of the number of MIPAS measurements containing a PSC signal and the entire number of measurements) poleward of $55^{\circ} \mathrm{S}$ at altitudes from 14 to $26 \mathrm{~km}$ in September 2002. Since the vertical extent of the instantaneous field of view of MIPAS is about $3 \mathrm{~km}$ at the tangent point, the highest altitudes where PSCs occurred can be determined at an uncertainty of $1.5 \mathrm{~km}$. A measurement is considered PSC measurement where the ratio of mean spectral radiances in the interval from 788.2 to $796.25 \mathrm{~cm}^{-1}$ and from 832.3 to $834.4 \mathrm{~cm}^{-1}$ is lower than the threshold value of 4.0 (Spang et al., 2004). Open triangles indicate availability of MIPAS data.

2005; Charlton et al., 2005), planetary waves of wavenumber 1 to 3 (Wang et al., 2005) caused a displacement, deformation, and, at above the $650 \mathrm{~K}$ potential temperature level (above approximately $25 \mathrm{~km}$ ), even a split of the polar vortex. The time of the major warming event coincides with the time of chlorine deactivation via $\mathrm{ClONO}_{2}$ formation (Höpfner et al., 2004; Richter et al., 2005). During the major warming the vortex was severely weakened above $900 \mathrm{~K}$, leading to excessive mixing of midlatitudinal air into the vortex (Konopka et al., 2005). 

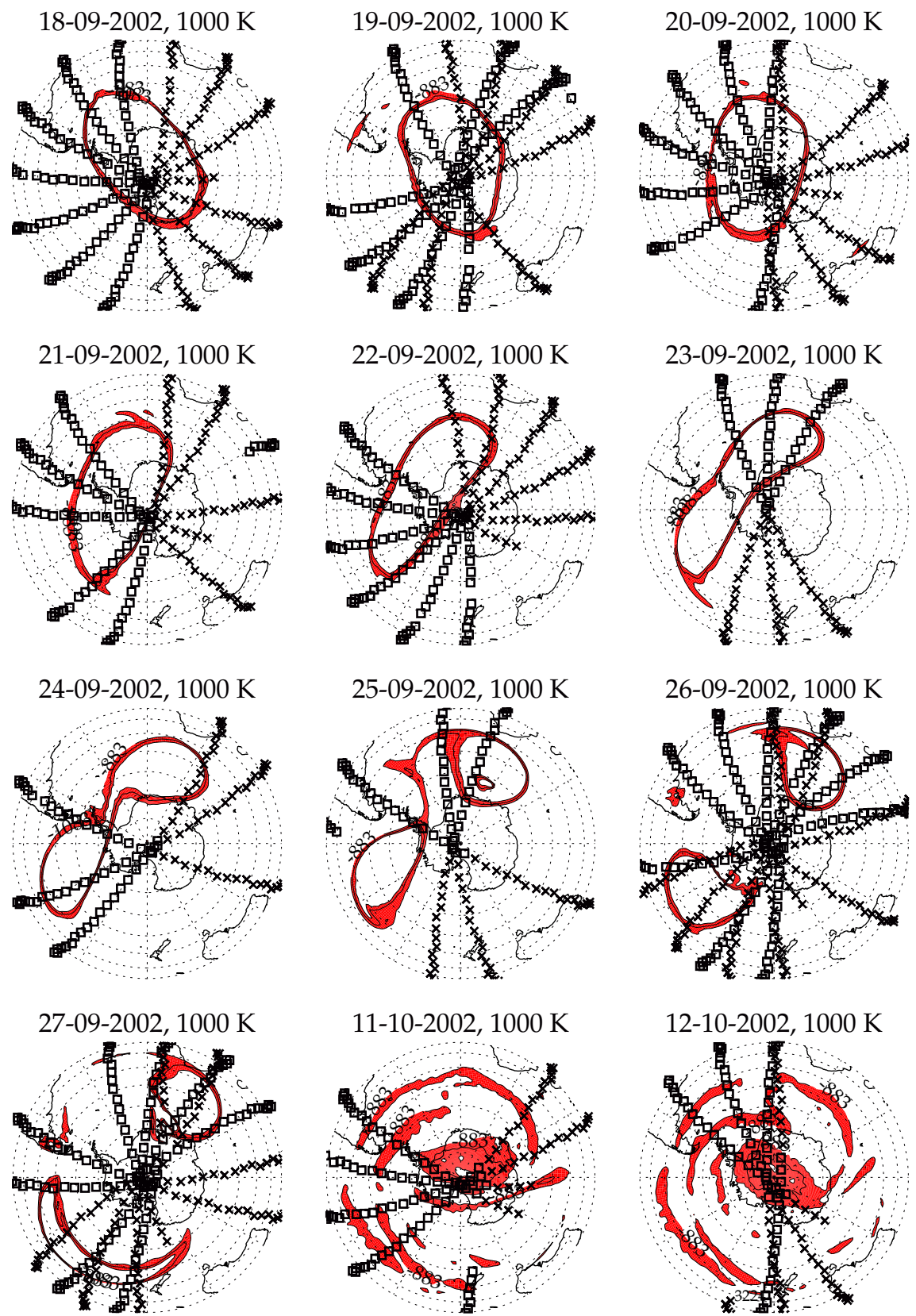

Fig. 2. The development of the Southern polar vortex in September 2002 at $1000 \mathrm{~K}$ potential temperature based on potential vorticity (PV) data provided by ECMWF. The red belt represents the vortex boundary, defined as $-1282.6 \mathrm{~km}^{2} \mathrm{~kg}^{-1} \mathrm{~s}^{-1}<\mathrm{PV}<855.1 \mathrm{~km}^{2} \mathrm{~kg}^{-1} \mathrm{~s}^{-1}$. Open boxes represent the geolocations of the MIPAS daytime measurements, while x symbols represent MIPAS nighttime measurements.

\section{MIPAS measurements}

The data set discussed in this paper was measured with the Michelson Interferometer for Passive Atmospheric Sounding (MIPAS), which is a limb emission spectrometer designed for measurement of trace species from space (Fischer et al., 2008). It is part of the instrumentation of the Environmental Satellite (Envisat), which was launched into its sunsynchronous polar orbit on 1 March 2002. Data presented here were recorded from 18 September to 27 September 2002 and 11 October to 13 October 2002. The data version used is $\mathrm{V} 2 \_\mathrm{HOCl}_{-}$2, as described in von Clarmann et al. (2006), where the $\mathrm{HOCl}$ data analysis is reported in detail. The precision and total error of a single $\mathrm{HOCl}$ profile are estimated at $0.05-0.08 \mathrm{ppbv}$ and $0.05-0.09 \mathrm{ppbv}$, respectively, at an altitude resolution of about $9 \mathrm{~km}$.

$\mathrm{ClONO}_{2}$ measurements have been provided by Höpfner et al. (2004). The single profile precision (total error) is estimated at $4-10 \%(6-11 \%)$ at an altitude resolution of 3.3$3.8 \mathrm{~km}$. ClO has been analyzed by Glatthor et al. (2004). 

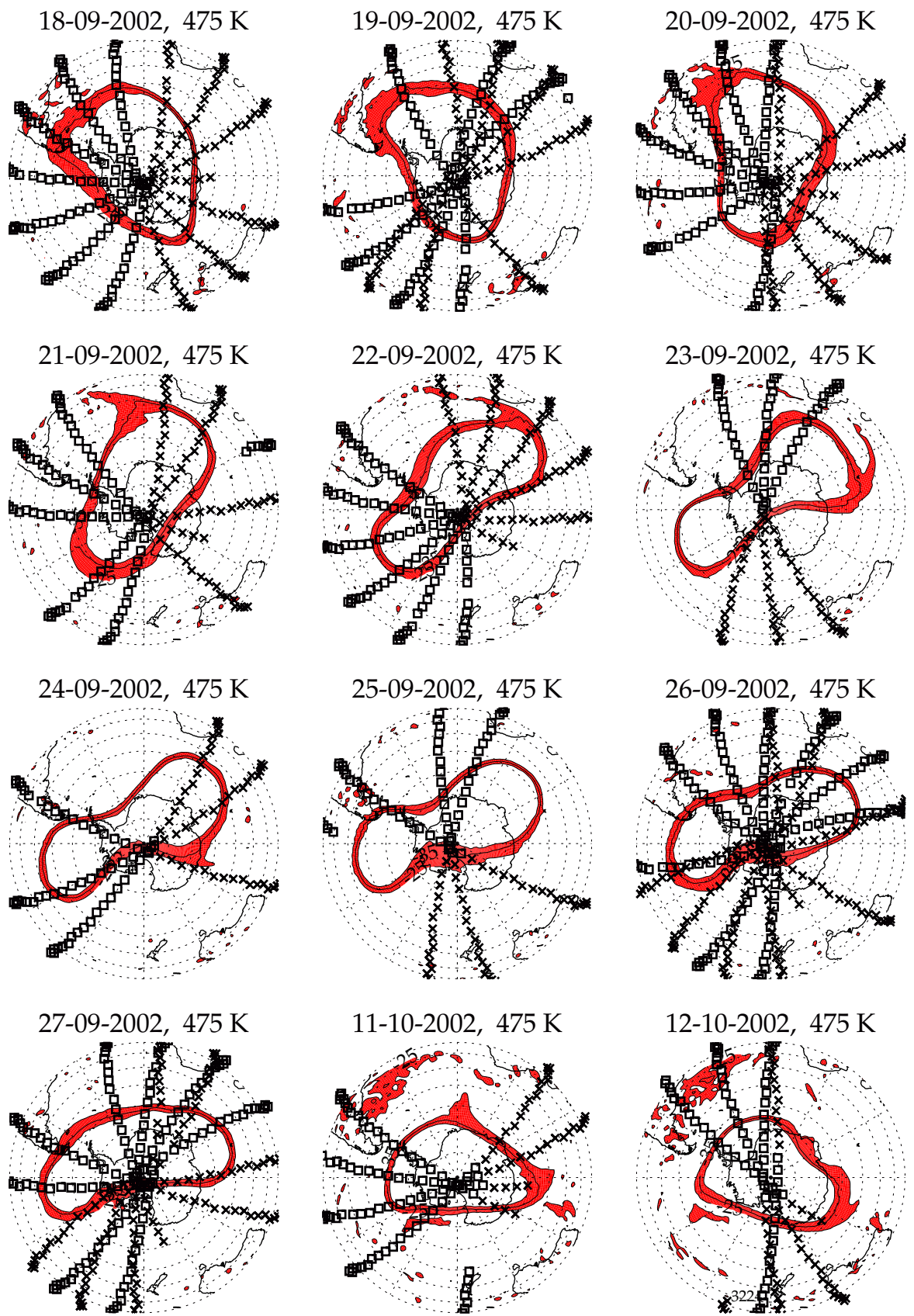

Fig. 3. Same as Fig. 2 but for $475 \mathrm{~K}$ potential temperature. The vortex boundary region is defined as $-45.0 \mathrm{~km}^{2} \mathrm{~kg}^{-1} \mathrm{~s}^{-1}<\mathrm{PV}<-30.0 \mathrm{~km}^{2} \mathrm{~kg}^{-1} \mathrm{~s}^{-1}$

The single profile precision (total error) in the lower stratosphere is estimated at $19-31 \%(29-36 \%)$ at an altitude resolution of $4 \mathrm{~km}$. ClO mixing ratios measured by MIPAS before 20 September and from 25 September onwards are in agreement with measurements by the Submillimeter Radiometer (SMR) on the Odin satellite (Ricaud et al., 2005). Unfortunately, no SMR measurements have been published for the 22-24 September period.
This study is entirely based on polar vortex averages and their temporal development (Fig. 4). For definition of the vortex edge, a procedure similar to that described by Nash et al. (1996) but with slightly modified parameter settings (Glatthor et al., 2005) was used. This resulted in a threshold of $-45 \times 10^{-6} \mathrm{~km}^{2} \mathrm{~kg}^{-1} \mathrm{~s}^{-1}$ at $475-\mathrm{K}$ potential temperature level for vortex air, which is conservative in a sense that the risk that vortex edge air is considered as vortex air is small. 

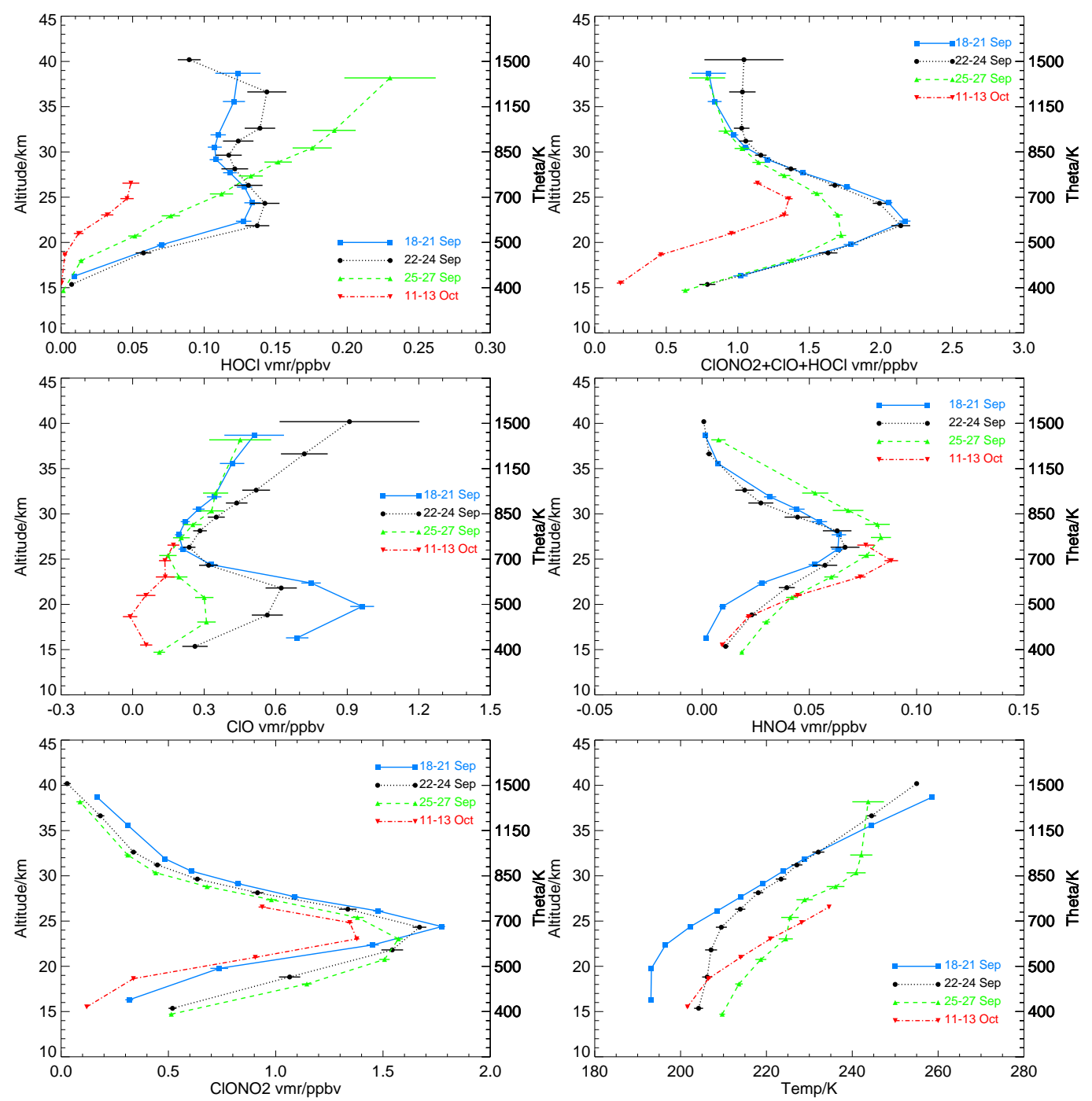

Fig. 4. Means of measured Antarctic vortex daytime mixing ratio profiles of $\mathrm{HOCl}, \mathrm{ClO}$, and $\mathrm{ClONO}_{2}$, (left panels, top to bottom), as well as $\mathrm{HOCl}+\mathrm{ClO}+\mathrm{ClONO}_{2}, \mathrm{HNO}_{4}$ and temperature (right panels, top to bottom) for the periods 18-21 September, 22-24 September, 25-27 September, and 11-13 October. Error bars represent the uncertainties of the meanvalues in terms of standard deviation divided by the square root of the number of averaged profiles. They include both measurement error and natural variability within the sample. For the $\mathrm{HOCl}+\mathrm{ClO}+\mathrm{ClONO}_{2}$ profiles, the $\mathrm{ClO}$ and $\mathrm{ClONO}_{2}$ profiles first were degraded to the $\mathrm{HOCl}$ altitude resolution to allow meaningful summation.

Above $700 \mathrm{~K}$, the extrapolation scheme as suggested by Lait (1994) was applied. This resulted in a vortex air threshold of $-1282.6 \times 10^{-6} \mathrm{~km}^{2} \mathrm{~kg}^{-1} \mathrm{~s}^{-1}$ at the $1000-\mathrm{K}$ potential temperature level. Potential vorticity data were taken from the T106 $\left(1.25^{\circ} \times 1.25^{\circ}\right.$ grid $)$ ECMWF analyses.

In order to avoid diurnal sampling artifacts, only daytime measurements (about 10:00 a.m. local time, solar zenith angles smaller than $94.5^{\circ}$ to $95.9^{\circ}$, depending on altitude) are considered. In particular, trapping of $\mathrm{ClO}$ in the dimer $\mathrm{ClOOCl}$, which is not measured by MIPAS, is negligible then at least for altitudes above about $30 \mathrm{~km}$ (Ruhnke et al., 1999b). Error bars of daily or episode mean values are the statistical uncertainties of the mean values, i.e. the standard errors of the mean. Due to irregular non-random sampling along the Envisat orbits, the actual variability of the atmospheric state within the polar vortex is assumed to be underestimated, because the true standard error of the mean, $\sigma_{\text {std.err }}$, depends not only on the standard deviation $\sigma$ and the sample size $n$ but also on the average inter-location correlation coefficient $\bar{r}$ :

$\sigma_{\text {std.err }}=\sqrt{\frac{\sigma^{2}(1+(n-1) \bar{r})}{n}}$

Since there is no obvious robust way to estimate $\bar{r}$, we ignore 
it and obtain the usual formulation of the standard error,

$\sigma_{\text {std.err }}=\frac{\sigma}{\sqrt{n}}$

and thus underestimate the standard errors of the mean for positive average correlation coefficients, which might be introduced by sampling along Envisat orbits (c.f., e.g. Jones et al. 1997 and references therein for discussion for a slightly different but related problem). As a consequence, the mean profiles do not necessarily represent the entire vortex but may contain local phenomena, and the non-representativeness might not be fully accounted by the standard errors. However, since $\mathrm{HOCl}, \mathrm{ClO}, \mathrm{ClONO}_{2}$ and $\mathrm{HNO}_{4}$ mean values have been obtained from the same observations, direct comparison of these species without sampling artifacts between species is possible.

\section{Model calculations}

The KASIMA model used in this study is a global circulation model including stratospheric chemistry for the simulation of the behaviour of physical and chemical processes in the middle atmosphere (Kouker et al., 1999; Ruhnke et al., 1999a; Reddmann et al., 2001). The meteorological component is based on a spectral architecture with the pressure altitude $z=-H \ln \left(p / p_{0}\right)$ as vertical coordinate where $H=7 \mathrm{~km}$ is a constant atmospheric scale height, $p$ is the pressure, and $p_{0}=1013.25 \mathrm{hPa}$ is a constant reference pressure. A horizontal resolution of $\mathrm{T} 42\left(2.84^{\circ} \times 2.84^{\circ}\right)$ has been used. In the vertical regime, 63 levels between 7 and $120 \mathrm{~km}$ pressure altitude and a $0.75 \mathrm{~km}$ spacing from 7 up to $22 \mathrm{~km}$ with a quadratic increase above were used. For the present studies, the version as described in Reddmann et al. (2001) is applied, but using ERA-40 analyses up to $18 \mathrm{~km}$, the relaxation term up to $1 \mathrm{hPa}$ and the prognostic part of the model up to $120 \mathrm{~km}$. This version yields realistic mean age of air values (Stiller et al., 2008) as opposed to models using analyses directly (see for example Monge-Sanz et al. 2007).

The chemical module consists of a stratospheric chemistry scheme including all important species belonging to the oxygen, nitrogen, hydrogen, chlorine and bromine families represented by 63 chemical species or families, which are involved in 107 bi- and termolecular reactions, 45 photodissociation and 10 heterogeneous reactions taking place on surfaces of polar stratospheric clouds (PSC) and on liquid sulfuric acid aerosols (Ruhnke et al., 1999a). The existence of NAT and ice is calculated with a thermodynamical approach assuming no supercooling according to the Hanson and Mauersberger (1988) parameterisation for nitric acid trihydrate (NAT) and the Marti and Mausersberger (1993) parameterisation for ice. The rate constants of the gas phase and heterogeneous reactions are taken from Sander et al. (2003). The photolysis rates are calculated online with the fast-j2 scheme of Brian and Prather (2002). In order to allow reasonably large timesteps $(6 \mathrm{~min})$ for the integration of production and loss rates the family concept is applied to $\left[\mathrm{O}_{\mathrm{x}}\right]=\left[\mathrm{O}_{3}\right]$ $+\left[\mathrm{O}\left({ }^{3} \mathrm{P}\right)\right]+\left[\mathrm{O}\left({ }^{1} \mathrm{D}\right)\right],\left[\mathrm{ClO}_{\mathrm{x}}\right]=[\mathrm{Cl}]+[\mathrm{ClO}]+2 \times[\mathrm{ClOOCl}]$, $\left[\mathrm{HO}_{\mathrm{x}}\right]=[\mathrm{H}]+[\mathrm{OH}]+\left[\mathrm{HO}_{2}\right],\left[\mathrm{NO}_{\mathrm{x}}\right]=[\mathrm{N}]+[\mathrm{NO}]+\left[\mathrm{NO}_{2}\right]$ $+\left[\mathrm{NO}_{3}\right]$ and $\left[\mathrm{BrO}_{\mathrm{x}}\right]=[\mathrm{Br}]+[\mathrm{BrO}]$.

The global model runs used in this paper were initialised from a long-term KASIMA simulation on 16 September 2002, 00:00 UT. To simulate as realistic distributions of chemical species inside the polar vortex as possible those trace species which are measured by MIPAS $\left(\mathrm{CH}_{4}\right.$ and $\mathrm{N}_{2} \mathrm{O}$ (Glatthor et al., 2005), $\mathrm{O}_{3}$ (Glatthor et al., 2006), $\mathrm{HNO}_{3}$ (Mengistu Tsidu et al., 2005; Wang et al., 2007), $\mathrm{HNO}_{4}$ (Stiller et al., 2007), $\mathrm{NO}$ and $\mathrm{NO}_{2}$ (Funke et al., 2005), $\mathrm{N}_{2} \mathrm{O}_{5}$ (Mengistu Tsidu et al., 2004), ClO (Glatthor et al., 2004), $\mathrm{ClONO}_{2}$ (Höpfner et al., 2004, 2007), $\mathrm{HOCl}$ (von Clarmann et al., 2006)) are re-initialised on 17 and 18 September inside the daytime polar vortex with MIPAS daytime averages. As each air parcel is exposed to sunlit conditions during these two days, this procedure leads to a complete reinitialisation of the entire vortex with MIPAS/Envisat data. Re-initialisation of $\left[\mathrm{ClO}_{\mathrm{x}}\right]$ is particularly difficult, since this $\mathrm{ClO}$ is the only $\mathrm{ClO}_{\mathrm{x}}$ component measured by MIPAS. Reinitialisation of $[\mathrm{ClO}]$ alone while keeping total $\left[\mathrm{ClO}_{\mathrm{x}}\right]$ constant does not help because the analytical repartitioning of $\left[\mathrm{ClO}_{\mathrm{x}}\right]$ which is implied by KASIMA's family concept would immediately restore the original KASIMA values except for changes related to re-initialised non- $\mathrm{ClO}_{\mathrm{x}}$ species which affect the partitioning. Instead, the total $\left[\mathrm{ClO}_{\mathrm{x}}\right]$ was scaled according to MIPAS $\mathrm{ClO}$ volume mixing ration (VMR). The goal of re-initialisation is to be able to attribute differences between the measured and the modeled atmospheric state to processes happening during the observed episode.

To ensure comparability and to reduce sampling artefacts, KASIMA vortex averages are calculated for the MIPAS geolocations, after interpolating the model results to these latitudes and longitudes. This approach of matched instead of random sampling (i.e. the use of model output at longitudes and latitudes of the MIPAS measurements) implies that differences between measured and calculated means of mixing ratios can be more significant than the combined standard errors suggest, because the latter have a common correlated sampling component. Since the position of the vortex in KASIMA is not always identical with that of the ECMWF analyses used as a selection criterion for MIPAS measurements, geolocations outside of the KASIMA model vortex have been disregarded.

In order to adjust the altitude resolution of the modeled profiles to that of MIPAS, MIPAS averaging kernels were applied to the model results. MIPAS data used for re-initialisation, however, are by definition provided at the MIPAS vertical resolution. In order to avoid inappropriate double smoothing, the modeled profiles are decomposed into an initial component (18 September data) and a timedependent component (difference between the actual modeled profiles and the initialisation profiles from 18 September) and the MIPAS averaging kernels are only applied to 
the latter component. For some applications where gains and losses of multiple chlorine species are compared, both the measured and modeled data are further degraded to the MIPAS $\mathrm{HOCl}$ vertical resolution.

\section{The temporal development of $\mathrm{HOCl}, \mathrm{ClO}$, and $\mathrm{ClONO}_{2}$ VMR inside the polar vortex}

The first available MIPAS data of this data set fall in the period of 18-24 September 2002. MIPAS HOCl measurements for this time are characterized by a pronounced double maximum structure (Fig. 4, upper left panel). First, we discuss the development of the upper maximum above $30 \mathrm{~km}$, which is ruled by gas phase chemistry (Reactions R1-R7). Then, there follows the discussion of the lower stratospheric $\mathrm{HOCl}$ maximum which is associated with additional heterogeneous chemistry (Reactions R8-R9). Due to irregular spatial sampling, the temporal development also includes a spatial component and thus cannot be understood as a pure time series.

\subsection{Gas phase chemistry regime}

On 18-19 September the Antarctic vortex still was intact and centered over the South pole. $\mathrm{HOCl}$ peak vortex daytime daily mean mixing ratios were found at $33-40 \mathrm{~km}$ altitude, reaching approximately $0.13 \pm 0.03 \mathrm{ppbv}$ (Fig. 4 , top left panel, blue lines). These values are lower than those measured in the midlatitudinal or tropic stratosphere, where peak mixing ratios up to $0.23 \mathrm{ppbv}$ were measured at these altitudes (von Clarmann et al., 2006). This is explained by a reduced availability of $\mathrm{HO}_{\mathrm{x}}$ at polar latitudes (about $40 \mathrm{pptv}$ compared to 150 or $200 \mathrm{pptv}$ at daytime midlatitudes or tropics, respectively, as calculated by KASIMA). Polar vortex daytime mean mixing ratios of $\mathrm{ClO}$ were $0.35 \pm 0.1 \mathrm{ppbv}$ at $33 \mathrm{~km}$ altitude between 18 and 21 September. In polar regions with little sunlight during polar winter, $\mathrm{ClO}$ is partly buffered in its reservoir $\mathrm{ClONO}_{2}$ (Fig. 4, middle left and bottom left panels, blue lines, and Fig. 5, middle and lower panels).

From 20-21 September, the vortex started to be distorted and displaced. During 22-24 September, as the vortex distortion continued during the major warming, $\mathrm{ClO}$ mixing ratios increased to values of around $0.5 \pm 0.2 \mathrm{ppbv}$ at $33 \mathrm{~km}$ (Fig. 4, middle left panel, black lines, and Fig. 5). During these days, a monotonic increase of ClO VMR is observed at all levels above $27 \mathrm{~km}$. This enhancement of ClO VMR was balanced by a reduction of the photochemically unstable $\mathrm{ClONO}_{2}$ by approximately 0.15 ppbv below $\sim 35 \mathrm{~km}$, while for higher altitudes the source of the excess $\mathrm{ClO}$ is not quite clear. During this period, $\mathrm{HOCl}$ VMR started to increase. Increasing $\mathrm{CH}_{4}$ and decreasing $\mathrm{CO}$ mixing ratios (appr. 0.3 to $0.4 \mathrm{ppmv}$ and 0.2 to $0.15 \mathrm{ppmv}$, respectively, at $1000 \mathrm{~K}$ ) indicate, that the vortex was severely destabilized during the major warming
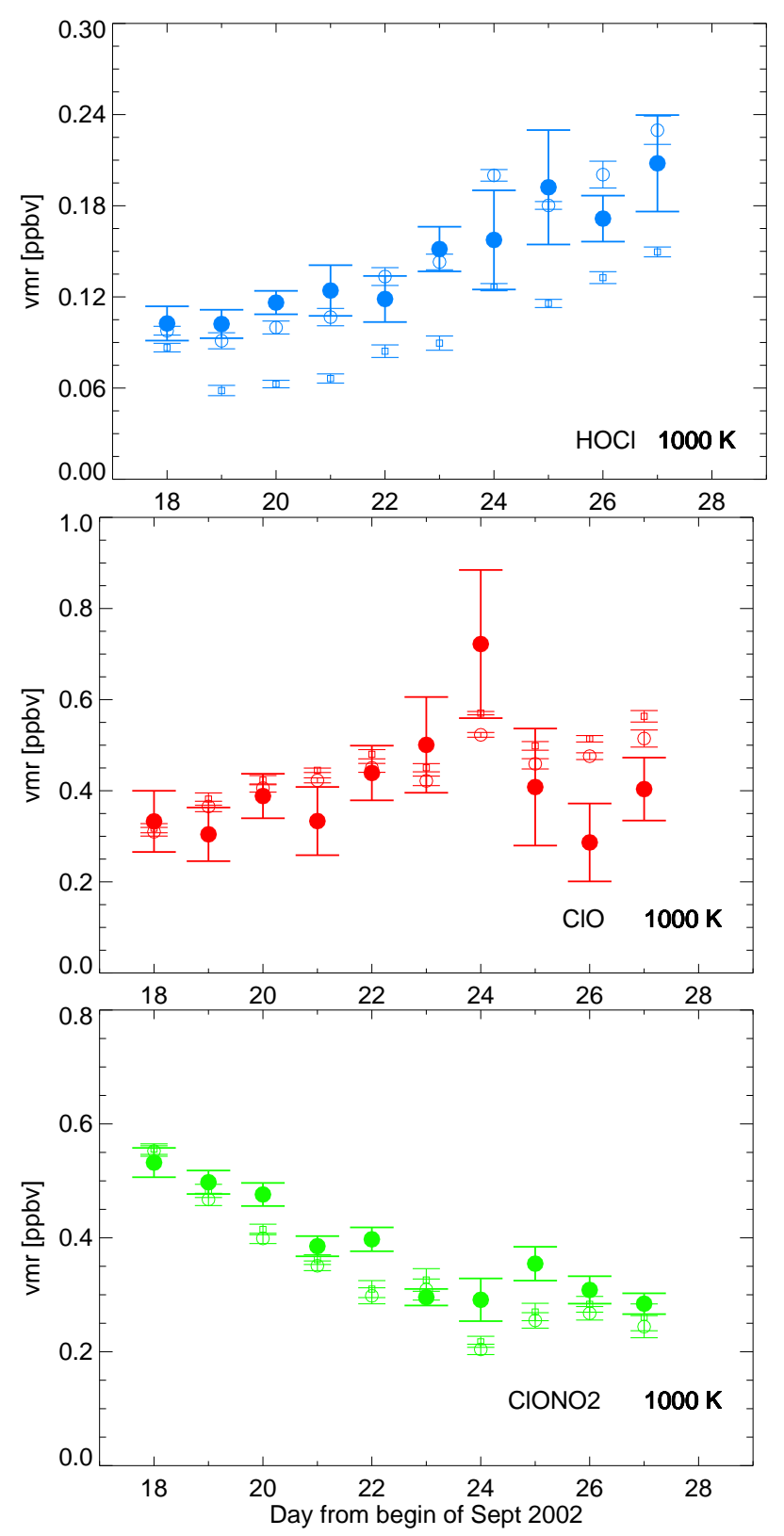

Fig. 5. Time series of $\mathrm{HOCl}$ (top panel), $\mathrm{ClO}$ (middle panel) and $\mathrm{ClONO}_{2}$ (bottom panel) daily vortex daytime averages in the polar vortex at $1000 \mathrm{~K}$, corresponding to approximately $33 \mathrm{~km}$ altitude. Solid symbols are MIPAS measurements, open symbols are KASIMA calculations. Open circles refer to model calculations with Reaction (R1) rate constants as measured by Stimpfle et al. (1979) (larger $\mathrm{HOCl}$ and lower $\mathrm{ClO}$ values), while small open squares are model calculations based on the reaction rate as recommended by Sander et al. (2006).

above $900 \mathrm{~K}$, and midlatitudinal air was mixed into the vortex.

From 24 to 25 September, when the major warming moved parts of the vortex to lower latitudes, measured $\mathrm{HOCl}$ vol- 
ume VMRs increased rapidly at $1000 \mathrm{~K}$ (Fig. 4, top left panel, green lines, Fig. 5). The reason is, that the sounded airmasses were more exposed to sunlight, which triggered more efficient $\mathrm{HO}_{\mathrm{x}}$ chemistry. The displacement of the vortex to lower latitudes and related exposure to sunlight are even more pronounced in the following days: The exceptionally high $\mathrm{HOCl}$ mixing ratios from 25-27 September are explained by midlatitudinal photochemistry, where in particular $\mathrm{HO}_{\mathrm{x}}$ chemistry is activated, in polar, thus ClO- and $\mathrm{ClONO}_{2}$ rich, airmasses. MIPAS measurements of vortex $\mathrm{HNO}_{4}$ (Stiller et al. 2007, Fig. 4, middle right panel), which also was observed to increase, support the explanation of accelerated odd hydrogen chemistry.

$\mathrm{HOCl}$ mixing ratios outside the displaced and distorted vortex were considerably lower (by approximately 20\%). This suggests that the highest atmospheric $\mathrm{HOCl}$ mixing ratios are expected whenever polar air is moved towards lower latitudes where enhanced exposure to sunlight increases the efficiency of the $\mathrm{HOCl}$ cycle Reactions (R1)-(R4) by the increasing availability of $\mathrm{ClO}$ and $\mathrm{HO}_{2}$. While certainly also $\mathrm{HOCl}$ loss reactions are more efficient in the presence of sunlight, availability of light causes a net increase of HOCl VMR due to the large amounts of $\mathrm{HO}_{\mathrm{x}}$ in the sunlit stratosphere.

To analyze the development of the chlorine partitioning, the sum of VMRs of $\mathrm{ClONO}_{2}+\mathrm{ClO}+\mathrm{HOCl}$ was calculated on the basis of MIPAS profiles degraded to the $\mathrm{HOCl}$ vertical resolution in order to allow meaningful summation. During the entire period from 18 to 27 September, the VMR of $\mathrm{ClONO}_{2}+\mathrm{ClO}+\mathrm{HOCl}$ was observed to stay approximately constant at about $30 \mathrm{~km}$ (Fig. 4, top right panel and Fig. 6), which justifies confidence in the data set. ClO VMR appeared to have increased during 22 and 24 September at the cost of $\mathrm{ClONO}_{2}$, and shows some unexplained temporary high (24 September) and low (26 September) values of which the significance is questionable. At the $1000 \mathrm{~K}$ potential temperature level (appr. $33 \mathrm{~km}$ altitude) measured VMR of $\mathrm{ClONO}_{2}+\mathrm{ClO}+\mathrm{HOCl}$ seems to have increased on 24 September, due to enhanced ClO VMR. Large overlapping error bars, however, indicate that this increase lacks statistical significance. The significance is even smaller than the error bars suggest since the variability of vortex measurements is underestimated due to non-random sampling given by the Envisat round tracks. HOCl VMR increased continuously from the beginning of the major warming to the end of the measurement period on 27 September (Fig. 5). Unfortunately, in the following phase of the split-vortex event, due to instrument shut-down, no more MIPAS measurements are available. From 11 October on, when MIPAS was operational again, the polar vortex had already dissolved above approximately $28 \mathrm{~km}$ altitude, prohibiting further analysis of the vortex airmasses there.

The measured and modeled temporal evolutions of the vortex daytime mixing ratios of the three chlorine species are in reasonable $\left(\mathrm{ClO}\right.$ and $\left.\mathrm{ClONO}_{2}\right)$ to excellent $(\mathrm{HOCl})$ agreement, when the rate constants proposed by Stimpfle

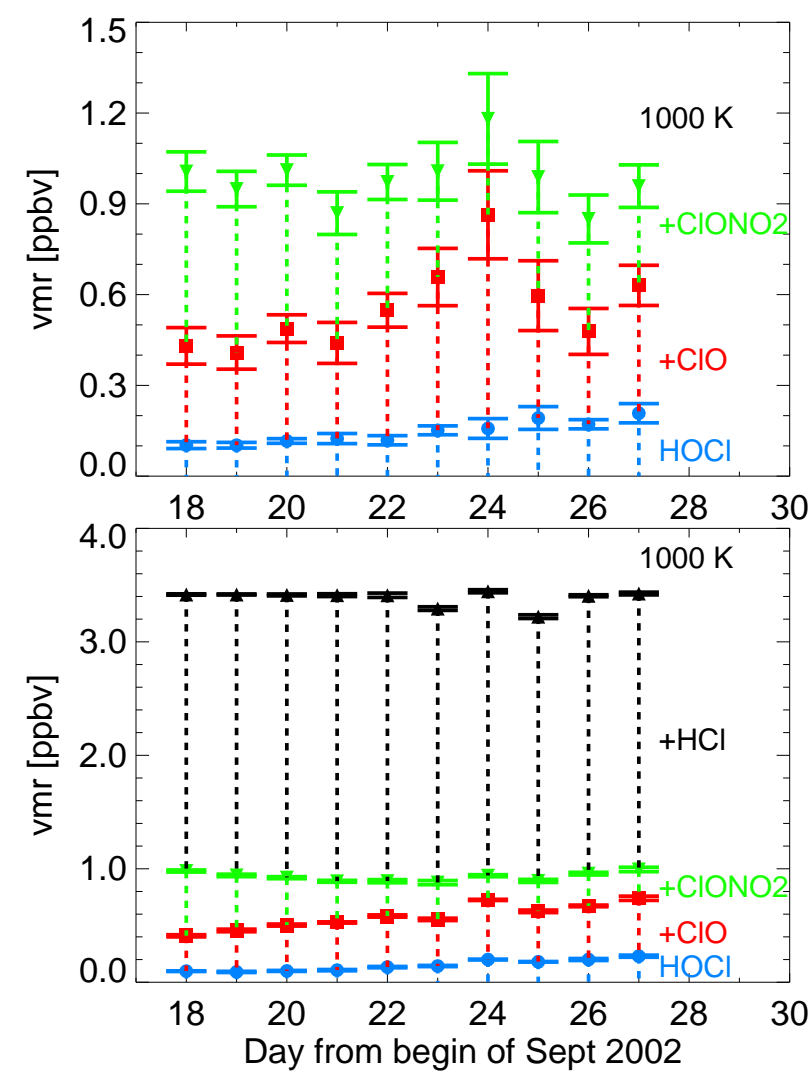

Fig. 6. Measured (upper panel) and modeled (lower panel) temporal development of chlorine partitioning in the polar vortex at $1000 \mathrm{~K}$, corresponding to approximately $33 \mathrm{~km}$ altitude. Blue dots indicate $\mathrm{HOCl} V M R s$; red squares indicate the $\mathrm{HOCl}+\mathrm{ClO}$ cumulative VMR and green triangles indicate the $\mathrm{HOCl}+\mathrm{ClO}+\mathrm{ClONO}_{2}$ cumulative VMR. The lower panel also includes modeled $\mathrm{HCl}$. These model results are based on the Reaction (R1) rate constants by Stimpfle et al. (1979). Error bars refer to the sums, not to the components. All data have been degraded to the vertical resolution of the $\mathrm{HOCl}$ retrieval in order to allow meaningful summation and intercomparison.

et al. (1979) are used for Reaction (R1), as proposed by Kovalenko et al. (2007). Using the rate constants of the current JPL recommendation (Sander et al., 2003, 2006) leads to significant underestimation of $\mathrm{HOCl}$ amounts. Despite of re-initialisation some discrepancies are observed already on 18 September, because different pressure and temperature profiles in the model and MIPAS data sets cause some ambiguities both in altitude assignment and conversion between mixing ratios and concentrations. The original MIPAS data and averaging kernels are provided as VMR on geometric altitudes, the model is re-initialised on pressure levels and chemistry is calculated on the basis of concentrations, and the vortex mean values are represented as VMR in potential temperature coordinates. Furthermore, there is one time-step of six minutes between re-initialisation and model output. 
At isentropic surfaces higher than $1000 \mathrm{~K}$ only very few MIPAS daytime vortex measurements were available because of the small extension of the vortex at these altitudes then. Therefore, analysis of these data remains somewhat speculative. The destabilisation of the vortex and related mixing during the major warming were even more pronounced at these high altitudes.

\subsection{Heterogeneous chemistry regime}

A lower stratospheric $\mathrm{HOCl}$ VMR maximum is visible at approximately $24 \mathrm{~km}$ in the 18-24 September data (Fig. 4 upper left panel, blue and black lines). This is an altitude domain, where chlorine activation is driven by heterogeneous chemistry on PSC particles, which also affects $\mathrm{HOCl}$ chemistry, either by Reaction (R8) or by Reaction (R1) after heterogeneous $\mathrm{ClO}$ formation. Last PSCs were observed by MIPAS on 22 September (Fig. 1). During 16 to 21 September MIPAS has detected some PSCs in the lowermost stratosphere at and below 17-18 km. On 17-18 September a few PSCs have been detected near the Peninsula region at altitudes up to $20-21 \mathrm{~km}$. Höpfner et al. (2006) have attributed occurrence of PSCs in this region to lee-waves triggered by the Peninsulan topography. Until 15 September PSCs were detected in MIPAS spectra even at tangent altitudes of about $23 \mathrm{~km}$ (Fig. 1). On 13 September high-reaching PSCs covered the largest area.

The measured lower stratospheric $\mathrm{HOCl}$ maximum on some days slightly exceeded even the upper maximum; daytime daily mean values reached 0.15 ppbv. No substantial variation between $10 \mathrm{a} . \mathrm{m}$. and $10 \mathrm{p} . \mathrm{m}$. measurements was observed here. $\mathrm{HOCl}$ mixing ratios were observed to decrease by appr. 5 ppt per day until 24 September at $475 \mathrm{~K}$ (Fig. 7, upper panel). From 25 September on, polar vortex mean daytime $\mathrm{HOCl}$ mixing ratios were substantially lower (20 pptv). $\mathrm{HOCl}$ follows the temporal development of $\mathrm{ClO}$. The rapid $\mathrm{ClO}$ decrease from 23 to 24 September goes along with an increase of $\mathrm{ClONO}_{2}$. In the October measurements, $\mathrm{HOCl}, \mathrm{ClO}$ and $\mathrm{ClONO}_{2}$ VMRs are low due to the usual chlorine deactivation into $\mathrm{HCl}$.

Oscillations in the time series of measured $\mathrm{ClO}$ VMR, as well as of $\mathrm{HOCl}+\mathrm{ClO}+\mathrm{ClONO}_{2}$, between 21 and 25 September and the discontinuity in the time series of $\mathrm{HOCl}$ between 24 and 25 September are partly attributed to irregular sampling (Fig. 8). This is particularly important since in this time period the vortex was rather inhomogeneous, and varying ozone concentrations led to different chlorine deactivations paths in different parts of the vortex (Grooß et al., 2005). Nevertheless, sampling artifacts would not obviously explain the observed time lag between the strong $\mathrm{ClO}$ and $\mathrm{HOCl}$ decrease on 24 and 25 September, respectively. This time lag suggests that $\mathrm{HOCl}$ was substantially destroyed within one day and this loss could not be efficiently compensated by production via Reaction (R1) in an atmosphere with low $\mathrm{ClO}$ abundances.
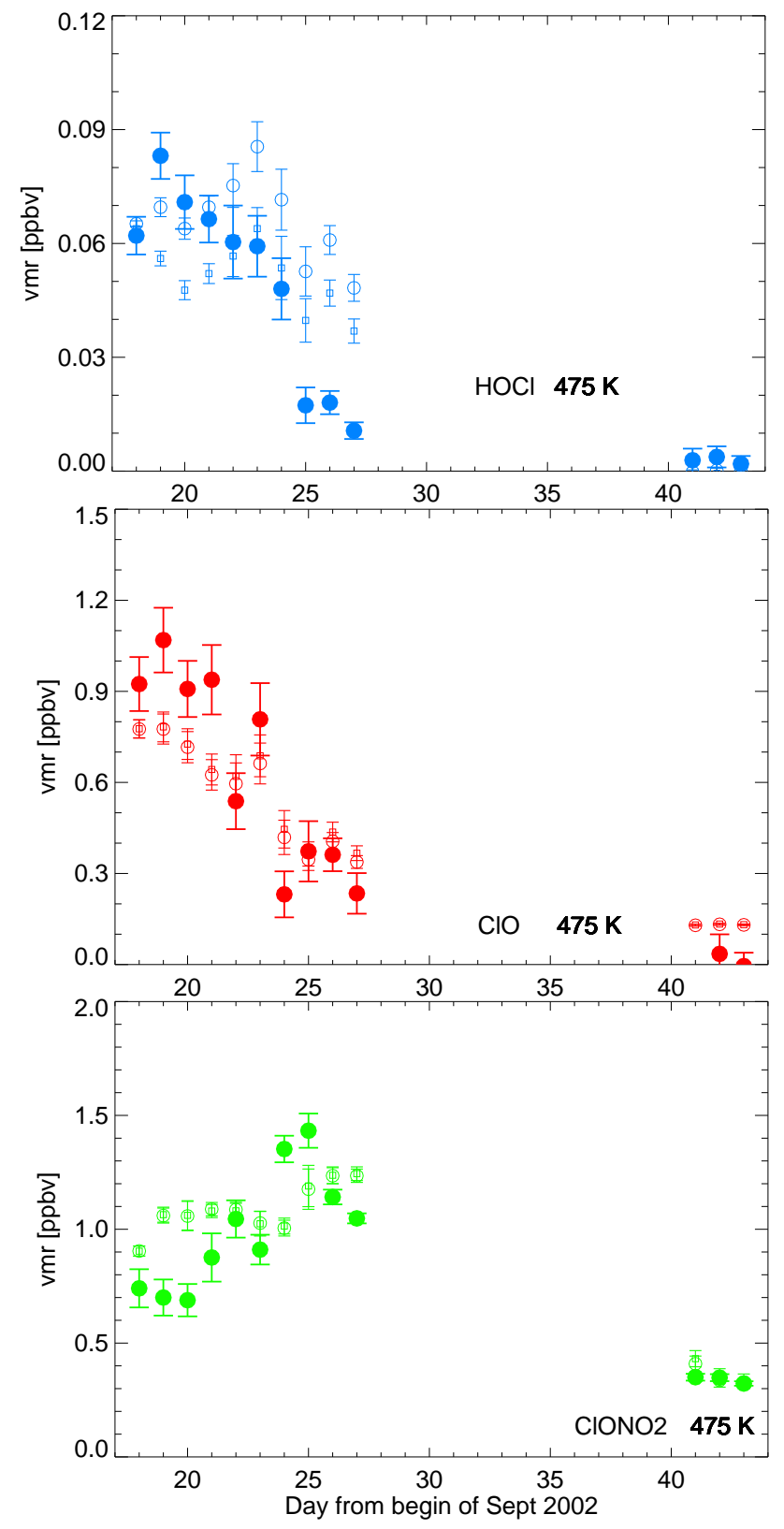

Fig. 7. Temporal development of $\mathrm{HOCl}$ (top panel), $\mathrm{ClO}$ (middle panel) and $\mathrm{ClONO}_{2}$ (bottom panel) in the polar vortex at $475 \mathrm{~K}$, corresponding to approximately $18 \mathrm{~km}$ altitude. For detailed explanation, see Fig. 5.

The rapid $\mathrm{HOCl}$ loss mentioned above happened during the vortex displacement, which had caused vortex air masses to be more exposed to sunlight, thus accelerating all three possible loss Reactions (R2), (R6) and (R7) which all depend on sunlight, (R2) as photolysis reaction, (R6) by the illumination-dependent $[\mathrm{OH}] /\left[\mathrm{HO}_{2}\right]$ ratio, and (R7) by UVillumination dependent availability of atomic oxygen. Due 


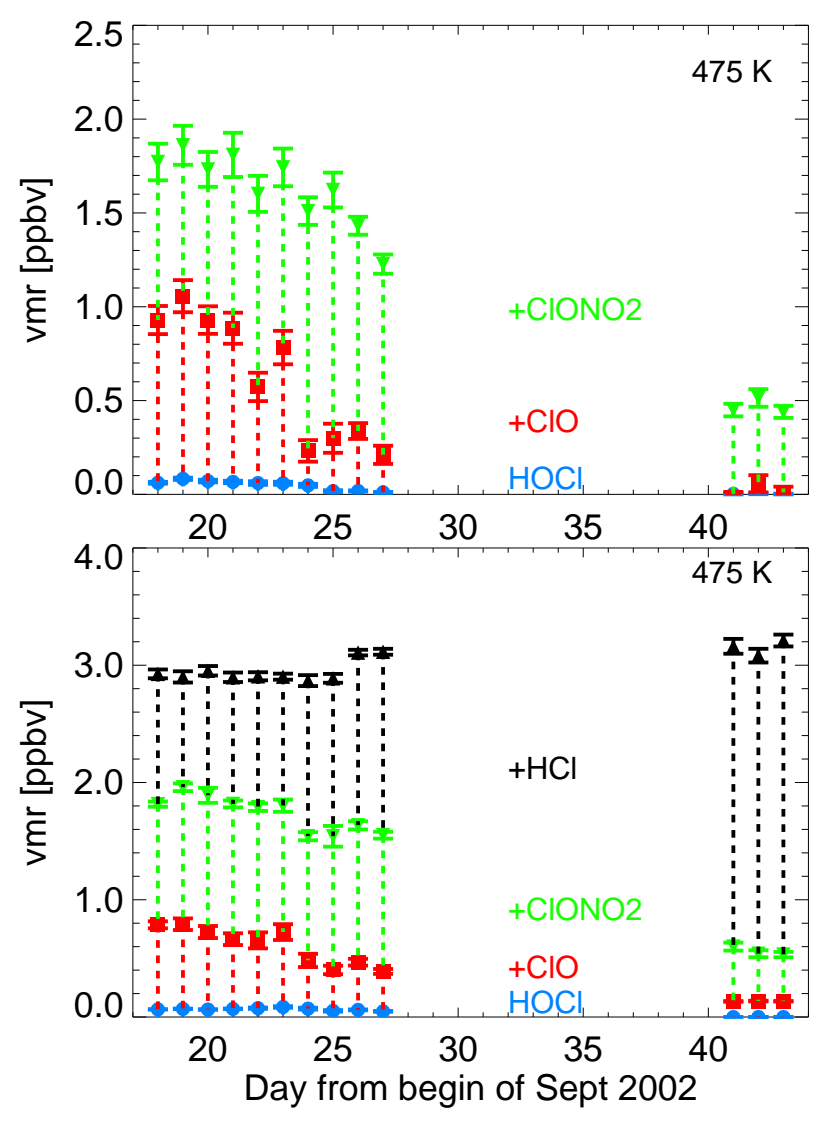

Fig. 8. Temporal development of chlorine partitioning in the polar vortex at $475 \mathrm{~K}$ as measured by MIPAS (upper panel) and modeled with KASIMA (lower panel), corresponding to approximately 18 km. For detailed explanation, see Fig. 6.

to ongoing $\mathrm{ClO}$-deactivation into $\mathrm{ClONO}_{2}$ (Fig. 4, middle and lower left panels, c.f. Höpfner et al. 2004), sufficient $\mathrm{ClO}$ abundances were no more available to compensate the $\mathrm{HOCl}$ loss by any substantial $\mathrm{HOCl}$ build up via Reaction (R1). $\mathrm{HO}_{\mathrm{x}}$ abundances as limiting reaction partner of Reaction (R1) can be ruled out, since $\mathrm{HNO}_{4}$ still was observed to increase (Fig. 4, middle right panel). From 25 September on, $\mathrm{HOCl}$ was observed to further decrease in this altitude range, and $\mathrm{HOCl}$ measurements on 11-13 October, which represent the Antarctic lower stratosphere after the reformation of the polar vortex, are below $0.06 \mathrm{ppbv}$ and do not differ from the typical global values at these altitudes (c.f. von Clarmann et al. 2006). All this suggests that largest $\mathrm{HOCl}$ abundances are to be expected during or immediately after a PSC period in $\mathrm{ClO}$-rich air.

Since PSCs appear in the model run only before 21 September (already reduced to one single occurrence at $50^{\circ} \mathrm{S}, 0^{\circ} \mathrm{E}$ by then) and not during the rest of the observation period, while still considerable $\mathrm{HOCl}$ levels are maintained, the part of $\mathrm{HOCl}$ also reproduced by the model must have been generated from previously heterogeneously gener- ated $\mathrm{ClO}$ via Reaction (R1) and not via direct heterogeneous chemistry (Reaction R8). Similar as in the gas phase chemistry regime, rate constants by Stimpfle et al. (1979) result in significantly larger $\mathrm{HOCl}$ mixing ratios than those recommended by Sander et al. (2006), which agree better with the 18-21 September MIPAS measurements. Since the $\mathrm{HOCl}$ abundance depends that strongly on the rate constants of gas phase Reaction (R1), the assumption of indirect heterogeneous $\mathrm{HOCl}$ formation as described above rather than direct heterogeneous $\mathrm{HOCl}$ formation via Reaction (R8) is further supported.

During the observation period, the atmosphere was quite warm (above $200 \mathrm{~K}$ at $23 \mathrm{~km}$ altitude in major parts of the vortex with only a limited area over the Peninsula and Weddell Sea with values of 190-200 K before 23 September), which led to early evaporation of mountain-wave PSCs. Thus, these PSCs were a localized phenomenon, and air was processed only when passing the PSC area, without any possibility of further heterogeneous reaction along the trajectory. The indirectly heterogeneously generated $\mathrm{HOCl}$ molecules, i.e. those which are generated via Reaction (R1) from heterogeneously produced $\mathrm{ClO}$, can even be produced when the air parcels contain no more PSCs which could act as an immediate $\mathrm{HOCl}$ sink via Reaction (R9).

From 22 September on, modeled $\mathrm{HOCl}$ mixing ratios are larger than the MIPAS ones, and the onset of $\mathrm{HOCl}$ loss seems to be delayed by about 2-3 days in the model calculation. This is consistent with the earlier decline of PSC occurrence in the model run. The heterogeneous HOCl loss Reaction (R9) was still possible in the real atmosphere while the PSC-free model atmosphere did not allow any heterogeneous reaction any longer. The average $\mathrm{HOCl}$ loss rates of MIPAS and KASIMA from 23 to 27 September are quite consistent (about $-0.01 \mathrm{ppbv/day).} \mathrm{A} \mathrm{slight} \mathrm{underestimation}$ of $\mathrm{ClO}$ mixing ratios along with overestimated $\mathrm{ClONO}_{2}$ in KASIMA results can also be attributed to ongoing heterogeneous chemistry in the early observation period not reproduced by the model. Poor reproduction of measured $\mathrm{ClO}$ values, however, also leaves room for speculation that the quantitative understanding of $\mathrm{ClO}$ dimer chemistry is insufficient (von Hobe et al., 2007).

\section{Conclusions}

The temporal development of the $\mathrm{HOCl}$ enhancement at $1000 \mathrm{~K}$ potential temperature level during the vortex displacement is understood as the triggering of midlatitudinal chemistry through enhanced sunlight in ClO-rich originally polar airmasses. Besides these illumination conditions, also mixing of humid and methane-rich midlatitudinal air into the vortex provided further $\mathrm{HO}_{\mathrm{x}}$ sources, making conditions even more favorable for $\mathrm{HOCl}$ build-up. In agreement with Kovalenko et al. (2007), we find that model calculations based on Reaction (R1) reaction rate constants by Stimpfle 
et al. (1979) reproduce the measurements better than those based on the current JPL recommendation (Sander et al., 2003, 2006). In the lower stratosphere, large $\mathrm{HOCl}$ abundances are attributed to heterogeneous chemistry on PSCs in the Peninsula region, a region where the stratosphere was coldest during this episode, and where in addition lee-waves may play a role. In the observation period, the $\mathrm{HOCl}$ abundances were $\mathrm{ClO}$, not $\mathrm{HO}_{\mathrm{x}}$ driven. Air transported through local temperature minima with PSC occurrence, either due to adiabatic lofting above tropospheric weather systems or due to mountain waves, encounters favorable conditions for large $\mathrm{HOCl}$ abundances, because after passing the PSC area the air is PSC-free. Thus sink Reaction (R9) has not to be considered further. Moreover, these mountain wave PSCs do not occur directly over the South pole but at latitudes of about $60^{\circ} \mathrm{S}$ to $70^{\circ} \mathrm{S}$, where illuminational conditions are more favorable of subsequent homogeneous $\mathrm{HO}_{\mathrm{x}}$ chemistry, which transfers a portion of the heterogeneously generated $\mathrm{ClO}$ into $\mathrm{HOCl}$.

Acknowledgements. ESA has provided MIPAS Level-1B data. Meteorological analysis data have been provided by ECMWF. The authors would like to thank Marc von Hobe and Simon Chabrillat for their helpful reviews.

Edited by: J. Burkholder

\section{References}

Abbatt, J. P. D. and Molina, M. J.: The Heterogeneous Reaction $\mathrm{HOCl}+\mathrm{HCl} \rightarrow \mathrm{Cl}_{2}+\mathrm{H}_{2} \mathrm{O}$ on ice and nitric acid trihydrate: Reaction probabilities and stratospheric implications, Geophys. Res. Lett., 19, 461-464, doi:10.1029/92GL00373, 1992.

Allen, D. R., Bevilacqua, R. M., Nedoluha, G. E., Randall, C. E., and Manney, G. L.: Unusual stratospheric transport and mixing during the 2002 Antarctic winter, Geophys. Res. Lett., 30, 1599, doi:10.1029/2003GL017117, 2003.

Brian, H. and Prather, M. J.: Fast-J2: Accurate simulation of stratospheric photolysis in global chemical models, J. Atmos. Chem., 41, 281-296, 2002.

Chance, K. V., Johnson, D. G., and Traub, W. A.: Measurement of stratospheric $\mathrm{HOCl}$ : Concentration profiles, including diurnal variation, J. Geophys. Res., 94, 11059-11069, doi:10.1029/ 89JD00692, 1989.

Charlton, A. J., O'Neill, A., Lahoz, W. A., and Berrisford, P.: The Splitting of the Stratospheric Polar Vortex in the Southern Hemisphere, September 2002: Dynamical Evolution, J. Atmos. Sci., 62, 590-602, 2005.

Crutzen, P. J., Müller, R., Brühl, C., and Peter, T.: On The Potential Importance of the Gase Phase Reaction $\mathrm{CH}_{3} \mathrm{O}_{2}+\mathrm{ClO} \rightarrow \mathrm{ClOO}$ $+\mathrm{CH}_{3} \mathrm{O}$ and the Heterogeneous Reaction $\mathrm{HOCl}+\mathrm{HCl} \rightarrow \mathrm{H}_{2} \mathrm{O}+$ $\mathrm{Cl}_{2}$ in "Ozone Hole" Chemistry, Geophys. Res. Lett., 19, 11131116, 1992.

Fischer, H., Birk, M., Blom, C., Carli, B., Carlotti, M., von Clarmann, T., Delbouille, L., Dudhia, A., Ehhalt, D., Endemann, M., Flaud, J. M., Gessner, R., Kleinert, A., Koopman, R., Langen, J., López-Puertas, M., Mosner, P., Nett, H., Oelhaf, H., Perron, G.,
Remedios, J., Ridolfi, M., Stiller, G., and Zander, R.: MIPAS: an instrument for atmospheric and climate research, Atmos. Chem. Phys., 8, 2151-2188, 2008, http://www.atmos-chem-phys.net/8/2151/2008/.

Funke, B., López-Puertas, M., von Clarmann, T., Stiller, G. P., Fischer, H., Glatthor, N., Grabowski, U., Höpfner, M., Kellmann, S., Kiefer, M., Linden, A., Mengistu Tsidu, G., Milz, M., Steck, T., and Wang, D. Y.: Retrieval of stratospheric $\mathrm{NO}_{\mathrm{x}}$ from 5.3 and $6.2 \mu \mathrm{m}$ nonlocal thermodynamic equilibrium emissions measured by Michelson Interferometer for Passive Atmospheric Sounding (MIPAS) on Envisat, J. Geophys. Res., 110, D09302, doi:10.1029/2004JD005225, 2005.

Glatthor, N., von Clarmann, T., Fischer, H., Grabowski, U., Höpfner, M., Kellmann, S., Kiefer, M., Linden, A., Milz, M., Steck, T., Stiller, G. P., Mengistu Tsidu, G., Wang, D. Y., and Funke, B.: Spaceborne $\mathrm{ClO}$ observations by the Michelson Interferometer for Passive Atmospheric Sounding (MIPAS) before and during the Antarctic major warming in September/October 2002, J. Geophys. Res., 109, D11307, doi:10.1029/ 2003JD004440, 2004.

Glatthor, N., von Clarmann, T., Fischer, H., Funke, B., Grabowski, U., Höpfner, M., Kellmann, S., Kiefer, M., Linden, A., Milz, M., Steck, T., Stiller, G. P., Mengistu Tsidu, G., and Wang, D. Y.: Mixing processes during the Antarctic vortex split in September/October 2002 as inferred from source gas and ozone distributions from ENVISAT-MIPAS, J. Atmos. Sci., 62, 787-800, 2005.

Glatthor, N., von Clarmann, T., Fischer, H., Funke, B., Gil-López, S., Grabowski, U., Höpfner, M., Kellmann, S., Linden, A. López-Puertas, M., Mengistu Tsidu, G., Milz, M., Steck, T., Stiller, G. P., and Wang, D.-Y.: Retrieval of stratospheric ozone profiles from MIPAS/ENVISAT limb emission spectra: a sensitivity study, Atmos. Chem. Phys., 6, 2767-2781, 2006, http://www.atmos-chem-phys.net/6/2767/2006/.

Grooß, J.-U., Konopka, P., and Müller, R.: Ozone Chemistry during the 2002 Antarctic Vortex Split, J. Atmos. Sci., 62, 860-870, 2005.

Hanson, D. and Mauersberger, K.: Laboratory studies of the nitric acid trihydrate: Implications for the south polar stratosphere, Geophys. Res. Lett., 15, 855-858, 1988.

Hanson, D. R. and Ravishankara, A. R.: Investigation of the reactive and nonreactive processes involving $\mathrm{ClONO}_{2}$ and $\mathrm{HCl}$ on water and nitric acid doped ice, J. Phys. Chem., 96, 2682-2691, 1992.

Höpfner, M., von Clarmann, T., Fischer, H., Glatthor, N., Grabowski, U., Kellmann, S., Kiefer, M., Linden, A., Mengistu Tsidu, G., Milz, M., Steck, T., Stiller, G. P., Wang, D.-Y., and Funke, B.: First spaceborne observations of Antarctic stratospheric $\mathrm{ClONO}_{2}$ recovery: Austral spring 2002, J. Geophys. Res., 109, D11308, doi:10.1029/2004JD004609, 2004.

Höpfner, M., Larsen, N., Spang, R., Luo, B. P., Ma, J., Svendsen, S. H., Eckermann, S. D., Knudsen, B., Massoli, P., Cairo, F., Stiller, G., v. Clarmann, T., and Fischer, H.: MIPAS detects Antarctic stratospheric belt of NAT PSCs caused by mountain waves, Atmos. Chem. Phys., 6, 1221-1230, 2006, http://www.atmos-chem-phys.net/6/1221/2006/.

Höpfner, M., von Clarmann, T., Fischer, H., Funke, B., Glatthor, N., Grabowski, U., Kellmann, S., Kiefer, M., Linden, A., Milz, M., Steck, T., Stiller, G. P., Bernath, P., Blom, C. E., Blumenstock, Th., Boone, C., Chance, K., Coffey, M. T., Friedl-Vallon, 
F., Griffith, D., Hannigan, J. W., Hase, F., Jones, N., Jucks, K. W., Keim, C., Kleinert, A., Kouker, W., Liu, G. Y., Mahieu, E., Mellqvist, J., Mikuteit, S., Notholt, J., Oelhaf, H., Piesch, C., Reddmann, T., Ruhnke, R., Schneider, M., Strandberg, A., Toon, G., Walker, K. A., Warneke, T., Wetzel, G., Wood, S., and Zander, R.: Validation of MIPAS CIONO2 measurements, Atmos. Chem. Phys., 7, 257-281, 2007,

http://www.atmos-chem-phys.net/7/257/2007/.

Johnson, D. G., Traub, W. A., Chance, K. V., Jucks, K. W., and Stachnik, R. A.: Estimating the abundance of $\mathrm{ClO}$ from simultaneous remote sensing measurements of $\mathrm{HO}_{2}, \mathrm{OH}$, and $\mathrm{HOCl}$, Geophys. Res. Lett., 22, 1869-1871, 1995.

Jones, P. D., Osborn, T. J., and Briffa, K. R.: Estimating Sampling Errors in Large-Scale Temperature Averages, J. Climate, 10, 2548-2568, 1997.

Konopka, P., Grooß, J.-U., Hoppel, K. W., Steinhorst, H.-M., and Müller, R.: Mixing and Chemical Ozone Loss during and after the Antarctic Polar Vortex Major Warming in September 2002, J. Atmos. Sci., 62, 848-859, 2005.

Kouker, W., Offermann, D., Küll, V., Reddmann, T., Ruhnke, R., and Franzen, A.: Streamers observed by the CRISTA experiment and simulated in the KASIMA model, J. Geophys. Res., 104, 16405-16418, 1999.

Kovalenko, L. J., Jucks, K. W., Salawitch, R. J., Toon, G. C., Blavier, J.-F., Johnson, D. G., Kleinböhl, A., Livesey, N. J., Margitan, J. J., Pickett, H. M., Santee, M. L., Sen, B., Stachnik, R. A., and Waters, J. W.: Observed and modeled $\mathrm{HOCl}$ profiles in the midlatitude stratosphere: Implication for ozone loss, Geophys. Res. Lett., 34, L19801, doi:10.1029/2007GL031100, 2007.

Krüger, K., Naujokat, B., and Labitzke, K.: The Unusual Midwinter Warming in the Southern Hemisphere Stratosphere 2002: A Comparison to Northern Hemisphere Phenomena, J. Atmos. Sci., 62, 603-613, 2005.

Lait, L. R.: An alternative form for potential vorticity, J. Atmos. Sci., 51, 1754-1759, 1994.

Larsen, J. C., Rinsland, C. P., Goldman, A., Murcray, D. G., and Murcray, F. J.: Upper Limits for Stratospheric $\mathrm{H}_{2} \mathrm{O}_{2}$ and $\mathrm{HOCl}$ from High Resolution Balloon-Borne Infrared Solar Absorption Spectra, Geophys. Res. Lett., 12, 663-666, 1985.

Lary, D. J.: Catalytic destruction of stratospheric ozone, J. Geophys. Res., 102, 21515-21526, 1997.

Marti, J. and Mausersberger, K.: A survey and new measurements of ice vapor pressure at temperatures between $170 \mathrm{~K}$ and $250 \mathrm{~K}$, Geophys. Res. Lett., 20, 363-366, 1993.

Mengistu Tsidu, G., von Clarmann, T., Stiller, G. P., Höpfner, M., Fischer, H., Glatthor, N., Grabowski, U., Kellmann, S., Kiefer, M., Linden, A., Milz, M., Steck, T., Wang, D.-Y., and Funke, B.: Stratospheric $\mathrm{N}_{2} \mathrm{O}_{5}$ in the austral spring 2002 as retrieved from limb emission spectra recorded by the Michelson Interferometer for Passive Atmospheric Sounding (MIPAS), J. Geophys. Res., 109, D18301, doi:10.1029/2004JD004856, 2004.

Mengistu Tsidu, G., Stiller, G. P., von Clarmann, T., Funke, B., Höpfner, M., Fischer, H., Glatthor, N., Grabowski, U., Kellmann, S., Kiefer, M., Linden, A., López-Puertas, M., Milz, M., Steck, T., and Wang, D. Y.: $\mathrm{NO}_{y}$ from Michelson Interferometer for Passive Atmospheric Sounding on Environmental Satellite during the Southern Hemisphere polar vortex split in September/October 2002, J. Geophys. Res., 110, D11301, doi: 10.1029/2004JD005322, 2005.
Monge-Sanz, B. M., Chipperfield, M. P., Simmons, A. J., and Uppala, S. M.: Mean age of air and transport in a CTM: Comparison of different ECMWF analyses, Geophys. Res. Lett., 34, L04801, doi:doi:10.1029/2006GL028515, 2007.

Nash, E. R., Newmann, P. A., Rosenfield, J. E., and Schoeberl, M. R.: An objective determination of the polar vortex using Ertel's potential vorticity, J. Geophys. Res., 101, 9471-9478, 1996.

Prather, M. J.: More rapid polar ozone depletion through the reaction of $\mathrm{HOCl}$ with $\mathrm{HCl}$ on polar stratospheric clouds, Nature, 355, 534-537, 1992.

Raper, O. F., Farmer, C. B., Zander, R., and Park, J. H.: Infrared Spectroscopic Measurements of Halogenated Sink and Reservoir Gases in the Stratosphere With the ATMOS Instrument, J. Geophys. Res., 92, 9851-9858, 1987.

Reddmann, T., Ruhnke, R., and Kouker, W.: Three-dimensional model simulations of $\mathrm{SF}_{6}$ with mesospheric chemistry, J. Geophys. Res., 106, 14525-14537, doi:10.1029/2000JD900700, 2001.

Ricaud, P., Lefèvre, F., Berthet, G., Murtagh, D., Llewellyn, E. J., Mégie, G., Kyrölä, E., Leppelmeier, G. W., Auvinen, H., Boonne, C., Brohede, S., Degenstein, D. A., de La Noë, J., Dupuy, E., El Amraoui, L., Eriksson, P., Evans, W. F. J., Frisk, U., Gattinger, R. L., Girod, F., Haley, C. S., Hassinen, S., Hauchecorne, A., Jimenez, C., Kyrö, E., Lautié, N., Le Flochmoën, E., Lloyd, N. D., McConnell, J. C., McDade, I. C., Nordh, L., Olberg, M., Pazmino, A., Petelina, S. V., Sandqvist, A., Seppälä, A., Sioris, C. E., Solheim, B. H., Stegman, J., Strong, K., Taalas, P., Urban, J., von Savigny, C., von Scheele, F., and Witt, G.: Polar vortex evolution during the 2002 Antarctic major warming as observed by the ODIN satellite, J. Geophys. Res., 110, D05302, doi:10.1029/2004JD005018, 2005.

Richter, A., Wittrock, F., Weber, M., Beirle, S., Kühl, S., Platt, U., Wagner, T., Wilms-Grabe, W., and Burrows, J. P.: GOME Observations of Stratospheric Trace Gas Distributions during the Splitting Vortex Event in the Antarctic Winter of 2002. Part I: Measurements, J. Atmos. Sci., 62, 778-785, 2005.

Ruhnke, R., Kouker, W., and Reddmann, T.: The influence of the $\mathrm{OH}+\mathrm{NO}_{2}+\mathrm{M}$ reaction on the $\mathrm{NO}_{\mathrm{y}}$ partitioning in the late Arctic winter 1992/1993 as studied with KASIMA, J. Geophys. Res., 104, 3755-3772, 1999a.

Ruhnke, R., Kouker, W., Reddmann, T., Berg, H., Hochschild, G., Kopp, G., Krupa, R., and Kuntz, M.: The vertical distribution of $\mathrm{ClO}$ at Ny-Ålesund during March 1997, Geophys. Res. Lett., 26, 839-842, 1999b.

Sander, S. P., Friedl, R. R., Ravishankara, A. R., Golden, D. M., Kolb, C. E., Kurylo, M. J., Huie, R. E., Orkin, V. L., Molina, M. J., Moortgat, G. K., and Finlayson-Pitts, B. J.: Chemical kinetics and photochemical data for use in atmospheric studies, evaluation number 14, 2003.

Sander, S. P., Golden, D. M., Kurylo, M. J., Moortgat, G. K., Wine, P. H., Ravishankara, A. R., Kolb, C. E., Molina, M. J., FinlaysonPitts, B. J., Huie, R. E., Orkin, V. L., Friedl, R. R., and KellerRudek, H.: Chemical kinetics and photochemical data for use in atmospheric studies: evaluation number 15, JPL Publication 062, Jet Propulsion Laboratory, California Institute of Technology, Pasadena, CA, 2006.

Solomon, S., Garcia, R. R., Rowland, F. S., and Wuebbles, D. J.: On the depletion of Antarctic ozone, Nature, 321, 755-758, 1986.

Spang, R., Remedios, J. J., and Barkley, M. P.: Colour indices for 
the detection and differentiation of cloud types in infra-red limb emission spectra, Adv. Space Res., 3, 1041-1047, doi:10.1016/ S0273-1177(03)00585-4, 2004.

Stiller, G. P., von Clarmann, T., Brühl, C., Fischer, H., Funke, B., Glatthor, N., Grabowski, U., Höpfner, M., Jöckel, P., Kellmann, S., Kiefer, M., Linden, A., López-Puertas, M., Mengistu Tsidu, G., Milz, M., Steck, T., and Steil, B.: Global distributions of $\mathrm{HO}_{2} \mathrm{NO}_{2}$ as observed by the Michelson Interferometer for Passive Atmospheric Sounding (MIPAS), J. Geophys. Res., 112, D09314, doi:10.1029/2006JD007212, 2007.

Stiller, G. P., von Clarmann, T., Höpfner, M., Glatthor, N., Grabowski, U., Kellmann, S., Kleinert, A., Linden, A., Milz, M., Reddmann, T., Steck, T., Fischer, H., Funke, B., LópezPuertas, M., and Engel, A.: Global distribution of mean age of stratospheric air from MIPAS SF6 measurements, Atmos. Chem. Phys., 8, 677-695, 2008,

http://www.atmos-chem-phys.net/8/677/2008/.

Stimpfle, R. M., Perry, R. A., and Howard, C. J.: Temperaturedependence of the reaction of $\mathrm{ClO}$ and $\mathrm{HO}_{2}$ radicals, J. Chem. Phys., 71, 5183-5190, 1979.

Toon, G. C., Farmer, C. B., Schaper, P. W., Lowes, L. L., and Norton, R. H.: Composition measurements of the 1989 Arctic winter stratosphere by airborne infrared solar absorption spectroscopy, J. Geophys. Res., 97, 7939-7961, 1992.

Traub, W. A., Johnson, D. G., and Chance, K. V.: Stratospheric Hydroperoxyl Measurements, Science, 247, 446-449, 1990.

von Clarmann, T., Wetzel, G., Oelhaf, H., Friedl-Vallon, F., Linden, A., Maucher, G., Seefeldner, M., Trieschmann, O., and Lefèvre, F.: $\mathrm{ClONO}_{2}$ vertical profile and estimated mixing ratios of $\mathrm{ClO}$ and $\mathrm{HOCl}$ in winter Arctic stratosphere from Michelson Interferometer for Passive Atmospheric Sounding limb emission spectra, J. Geophys. Res., 102, 16157-16168, 1997. von Clarmann, T., Glatthor, N., Grabowski, U., Höpfner, M., Kellmann, S., Linden, A., Mengistu Tsidu, G., Milz, M., Steck, T., Stiller, G. P., Fischer, H., and Funke, B.: Global stratospheric $\mathrm{HOCl}$ distributions retrieved from infrared limb emission spectra recorded by the Michelson Interferometer for Passive Atmospheric Sounding (MIPAS), J. Geophys. Res., 111, D05311, doi: 10.1029/2005JD005939, 2006.

von Hobe, M., Salawitch, R. J., Canty, T., Keller-Rudek, H., Moortgat, G. K., Grooß, J.-U., Müller, R., and Stroh, F.: Understanding the kinetics of the $\mathrm{ClO}$ dimer cycle, Atmos. Chem. Phys., 7, 3055-3069, 2007, http://www.atmos-chem-phys.net/7/3055/2007/.

Wang, D. Y., von Clarmann, T., Fischer, H., Funke, B., GarcíaComas, M., Gil-López, S., Glatthor, N., Grabowski, U., Höpfner, M., Kellmann, S., Kiefer, M., Koukouli, M. E., Lin, G., Linden, A., López-Puertas, M., Mengistu Tsidu, G., Milz, M., Steck, T., and Stiller, G. P.: Longitudinal Variations of Temperature and Ozone Profiles Observed by MIPAS during the Antarctic Stratosphere Sudden Warming of 2002, J. Geophys. Res., 110, D20101, doi:10.1029/2004JD005749, 2005.

Wang, D. Y., Höpfner, M., Mengistu Tsidu, G., Stiller, G. P., von Clarmann, T., Fischer, H., Blumenstock, T., Glatthor, N., Grabowski, U., Hase, F., Kellmann, S., Linden, A., Milz, M., Oelhaf, H., Schneider, M., Steck, T., Wetzel, G., López-Puertas, M., Funke, B., Koukouli, M. E., Nakajima, H., Sugita, T., Irie, H., Urban, J., Murtagh, D., Santee, M. L., Toon, G., Gunson, M. R., Irion, F. W., Boone, C. D., Walker, K., and Bernath, P. F.: Validation of nitric acid retrieved by the IMK-IAA processor from MIPAS/ENVISAT measurements, Atmos. Chem. Phys., 7, 721-738, 2007,

http://www.atmos-chem-phys.net/7/721/2007/. 